Although the committee was not asked to study the damage caused by oil pollution, the ill-effects indicated in the report are: (a) the spoiling of beaches and the amenities of coastal resorts; $(b)$ the destruction and injury of sea birds ; $(c)$ the fouling of boats, fishing gear, quays, etc.; $(d)$ risk of fire in harbours and other enclosed waters.

The oil is also deleterious to marine flora, and the widespread disappearance during the past twenty-five years of the eel-grass Zostera marina, a plant of the inter-tidal zone, is believed by some to have been mainly brought about by oil pollution. The symptoms of the disease of this plant, including the final stage in which it is killed by a parasite, Labrynthula, are very similar to the symptoms observed on similar land plants when oil is used as the killing agent. The large areas of eel-grass provided a special habitat for fish and food for wildfowl, and the long fronds were effective breakwaters. Where large areas of eel-grass disappeared there has been a decrease in molluses and crustaceans, wildfowl have moved elsewhere, and erosion of the coastline has often followed. The conclusions are that waste oil not only fouls, but also kills, and that the cost of the present scale of pollution of the seas of the world is such that vigorous action must be taken at once to halt this menace; and then, as quickly as practicable, on an international basis, to eradicate the sources of oil pollution of the seas.

The highest praise is due to the committee for the presentation of this excellent report within so short a time, and it is hoped that prompt action by the Government will follow, thus giving a lead to other countries on essential standards of cleanliness.

\section{THE INTERACTION OF SCIENCE AND SOCIETY}

$I^{\mathrm{N}}$ $\checkmark$ recent years, many papers and books surveying the impact of science on society and the influence of the modern democratic State on the progress of science have been published. Some have been confined to a narrow field of interest, whereas others have attempted a survey of the whole broad problem. A recent book on this subject is Mr. Bernard Barber's "Science and the Social Order"*; although this refers particularly to the American scene, its general conclusions are worth consideration in a wider context.

In his view of the nature of science, Mr. Barber follows Dr. J. B. Conant, whom he quotes extensively, adopting a matter-of-fact and realistic treatment which is a valuable feature of his book. $\mathrm{H}_{\Theta}$ shows both the reason why science alone can never provide for man a complete adjustment to the natural and social world, and also the way in which the good conceptual schemes, which Dr. Conant regards as the essential component of all science, are interwoven with controlled experi-

* Science and the Social Order. By Bernard Barber. Pp. vii +288. (London: George Allen and Unwin, Ltd,, 1953.) 208. net. mentation in scientific advance. A clear understanding of this relation is, as he rightly insists, of great importance in considering the possibilities and technique of scientific advance, especially in the social and biological fields. It is of the greater importance because modern man has to learn not only about, but also to live with, science.

The relation between the conceptual schemes of science and the body of belief and knowledge usually termed 'common sense' is an aspect of the nature of science which is discussed more fully in his review of the development of science. Here he stresses some conceptions which he regards as essential for understanding the social aspects of science: the universality of human rationality; the continuity of the evolution of science; the importance of some social influences, including the economic factor, on the development of science; the relative autonomy of science, considered as a component of society; and the reciprocality of influence between science and the other components of society. Generally, he follows Whitehead and rejects the Marxist view that science is a wholly dependent part of society, moulded fundamentally by the economic factor; he holds that science has a reciprocal influence on the other sectors of society, and thus makes his examination of the characteristics of modern society which are favourable to the development of science more realistic. Incidentally, he brings out the significance of Sir Edward Appleton's recent plea for the pursuit of science for its own sake.

Mr. Barber believes both that only in certain types of society can science flourish, and that without a continuous and healthy development and application of science such a society cannot function properly. Discountenancing extreme statements regarding the effect of political ideology on scientific work, his general discussion of the social organization of science and the affinity between the accepted values of science or the characteristics of the scientific attitude and those of liberal societies is a wholesome corrective to some current polemics. Scionce, he points out, has its moral values, as well as its conceptual schemes. 'Pure' science is concerned primarily and immediately with the development of conceptual schemes, and applied science with making such schemes instruments to some purpose other than the pursuit of conceptual schemes for their own sake. The moral values of science are also involved, however, just as they are in the motivation of individual scientists, which may determine whether they adopt a career in science or in technology; and although in technology rationality may have a higher limit, other values cannot be disregarded even there.

While Mr. Barber's discussion of the role of the scientific and professional societies and their interrelations is primarily concerned with conditions in the United States, his observations frequently have a much wider bearing and are highly relevant in considering the future of professional organizations and of scientific societies in Great Britain. Tho 
social pattern may differ; but the real problems are essentially the same, though the relative importance of particular factors may vary considerably. For example, the comparatively low prestige of all Government employment in the United States has depressed the public prestige of Government scientific research in that country, with an effect on recruitment the reverse of that which has existed in Great Britain, at least until recently.

In recognizing the interaction of science and society, Mr. Barber discounts any attempt to exaggerate the influence of social conditions on invention or discovery, and he dismisses the allegation that inventions are suppressed for narrow or selfish interests. His discussion of the technological change is, however, brief and stimulating rather than penetrating; and here again he insists on the importance of regarding all the moral values within the context of which science functions. He gives a timely warning against the danger of two extremist positions in accepting any kind of social responsibility of science: acceptance of exclusive responsibility is as dangerous as the 'ivory tower' attitude with its rejection of all responsibility for the social consequences of scientific discoveries. His discussion of what are often called the social responsibilities of science is realistic; for it is clearly impossible to predict the long-term social consequences of a particular discovery, or to dogmatize on the continuous interaction of social factors and science.

The great need, as Mr. Barber sees it, is for more understanding between the physical scientist and the social scientist. Science, he holds, has the obligation to extend its method to the study of the social and political process itself; and further, he makes the point that the social and natural sciences are not so completely separable from one another as is commonly assumed. Even the protagonists of the wholesale planning of science and those of freedom in general differ less than they think, and Mr. Barber remarks with some truth that they could probably collaborate very profitably in the kind of concrete prediction and formulation of programmes that occur daily in science. More of the method of science itself is, in fact, required at exactly this point.

Mr. Barber's critical analysis of the nature and prospects of the social sciences is the more persuasive because of its realism. He never claims too much, and he gives due weight alike to the rationality in society which gives social science its freedom to investigate rationally the very fundamentals of society, to the high degree of indeterminacy in most of the information classed as social science and to the non-rational elements in human life which are no more entirely ignorance and error than that the non-empirical elements are all 'unreal'. Natural science, he reminds us, has not yet given, and never will give, us complete control of the physical and biological universe in which we live. Knowledge does not need to be complete to be effective, and because human knowledge is only one of the factors that determine social behaviour its influence is for that reason limited; we need not fear that social science will create the possibility of complete social control. On the contrary he believes that, just as natural science has been used to give us relative abundance, social science can be used to give us freedom in the same relative measure; nor will seience in our present society achieve maturity until social science comes of age with the natural sciences. One of the best auguries of that may well be the increasing awareness among social scientists of the nature of the scientific task which confronts them. Mr. Barber suggests, in conclusion, that in this twentieth century we may see the emergence of the conception of an 'order of human nature', with a fructifying influence on the development of social science comparable with that which the conception of an 'order of nature' has had on the development of natural science since the seventeenth century. His book provides evidence that this optimism is at least reasonable; the arguments merit careful study and discussion.

\section{STUDIES IN ANTHROPOLOGY}

\section{Anthropology Today}

An Encyclopedic Inventory. Prepared under the chairmanship of A. L. Kroeber. Pp. xv+966. (Chicago : University of Chicago Press; London: Cambridge University Press, 1953.) 67s. 6d. net.

THE occasion for this collection of studies on the I various fields of anthropology was the organization of an international discussion conference in New York last year by the Wenner-Gren Foundation for Anthropological Research in celebration of its tenth anniversary. The authors are mostly, but by no means exclusively, American, and their contributions were prepared and distributed in advance among the members of the conference, both to provide points of departure of a series of discussions and an inventory of outstanding recent advances in anthropology. It should be noted that a detailed and lively report on the views developed during the conference itself has also been published as "An Appraisal of Anthropology Today" (Tax, S., et al., editors. Chic. Univ. Press, 1953).

Owing largely, it would appear, to the traditions and circumstances of university teaching and research there, the interconnexions between the various branches of anthropology have been more effectively maintained in the United States than in Britain and the rest of Europe. This is reflected in both the wide coverage and the conscious efforts at integration which are apparent in this inventory. Thus, the papers variously devoted to aspects of human evolution, to the long-term culture history of the major regions of the world, to analysos of cultural processes and the range of factors underlying cultural variation and development show, for the most part, an awareness of problems, methods and findings in other fields. On the other hand, it can scarcely be claimed that either in coverage or arrangement this series of some fifty papers affords as well-organized and encyclopædic a view of approaches and results as could be desired. Practical and human limitations no doubt account in part for omission and defects, but the grouping of the papers into three main sections labelled "Problems of the Historical Approach", "Problems of Process" and "Problems 